УДК 658:1:658.8:005.21

https://doi.org/10.52058/2708-7530-2021-11(17)-296-304

Лихолат Світлана Михайлівна кандидат економічних наук, доцент, доцент кафедри маркетингу і логістики, Національний університет «Львівська політехніка», вул. Степана Бандери, 12, м. Львів, 79000, тел.: (032) 258-26-25, e-mail: s1925p@i.ua,https://orcid.org/0000-0002-0517-6852

Підпалюк Яна Віталіївна магістр кафедри маркетингу і логістики, Національний університет «Львівська політехніка», вул. Степана Бандери, 12, м. Львів, 79000, тел.: (032) 258-26-25, e-mail: yanapidpalyk@gmail.com, https://orcid.org/ 0000-0001-6360-3106

\title{
СУЧАСНІ АСПЕКТИ ФОРМУВАННЯ МАРКЕТИНГОВОЇ КОМУНІКАЦІЙНОЇ ПОЛІТИКИ
}

Анотація. Досліджуючи тенденції розвитку вітчизняних підприємств встановлено зростання ролі маркетингової комунікаційної політики. Ефективна комунікація із цільовою аудиторією стала вирішальним фактором успішної діяльності підприємства. Встановлено, що споживач потребує не просто придбати товар який задовільнить їх потреби, але й потребує комунікації 3 виробником цього товару. Дана тенденція впливає на формування культури споживача та спостерігається в усьому світі. Зазначено, що формування маркетингової комунікаційної політики необхідне для того, аби суспільство отримувало більше інформації про діяльність підприємств, торгову марку, історію, процес виробництва та зміну ціни на продукцію. Акцентується увага на тому, що завдяки цьому ефективній комунікації можна збільшити ринкову частку підприємства, розширити цільову аудиторію, сформувати позитивний імідж та високу ринкову позицію. Зазначається, що за сучасних умов господарювання застосування лише стандартних та загальновідомих способів виведення продукту на ринок $є$ непридатним для довготривалого існування товару на ринку що пов'язано із наявністю товаріваналогів і, як наслідок, представлений товар може бути незамічений цільовою аудиторією. Окреслено ключові аспекти інтегрованих маркетингових систем (інтеграція виробу, інтеграція позиціонування, інтеграція плану-графіку). В підсумку зазначено, що успішне просування товару на ринку можливе лише за умови використання продуманого процесу маркетингової комунікаційної політики із врахуванням факторів інформування, посилення довіри до виробника, нагадування покупцю про наявність та функціонал товару, покращення збуту, напрацювання лояльного ставлення збоку споживача та покращення сприятливого й пізнаваного іміджу підприємства. 
Ключові слова: маркетингова комунікаційна політика, маркетингові комунікації, ефективна комунікація, маркетингові інструменти, інтегрована маркетингова система.

Lykholat Svitlana Mykhailivna Candidate of economic sciences, associate professor, Associate Professor of Marketing and Logistics Department, The National University «Lviv Polytechnic», Stepana Bandery St., 12, Lviv, 79000, tel.: (032) 258-26-25, e-mail: s1925p@i.ua, https://orcid.org/0000-0002-0517-6852

Pidpaliuk Yana Vitaliivna Master of Marketing and Logistics Department, The National University «Lviv Polytechnic», Stepana Bandery St., 12, Lviv, 79000, tel.: (032) 258-26-25, e-mail: yanapidpalyk@gmail.com, https://orcid.org/00000001-6360-3106

\section{MODERN ASPECTS OF MARKETING COMMUNICATION POLICY FORMATION}

Abstract. Investigating the development trends of domestic enterprises, it was established that the role of marketing communication policy is growing. Effective communication with the target audience has become a decisive factor in the successful operation of the enterprise. It is revealed that the consumers want not only to buy a product that will meet their needs, but also require communication with the manufacturer of this product. This trend affects the formation of consumer's culture and is observed around the world. It is noted that the formation of marketing communication policy is necessary for society to receive more information about the activities of enterprises, brand, history, production process and changes in products prices. It is emphasized that due to this effective communication it is possible to increase the market share of the enterprise, expand the target audience, and form a positive image and a high market position. It is noted that in modern business conditions, the use of only standard and well-known methods of bringing the product to the market is unsuitable for long-term existence of the product on the market due to the availability of similar products and, consequently, the product may go unnoticed by the target audience. The key aspects of integrated marketing systems (product integration, positioning integration, schedule integration) are outlined. As a result, it is noted that the successful promotion of goods on the market is possible only if you use a well-judged process of marketing communication policy, taking into account information factors, strengthening trust in the manufacturer, reminding the buyer of the availability and functionality of the product, improving sales, gaining consumer's loyalty and improving the favorable and recognizable image of the enterprise.

Keywords: marketing communication policy, marketing communications, effective communication, marketing tools, integrated marketing system. 
Постановка проблеми. Тенденції розвитку вітчизняних підприємств дають підставу стверджувати про зростання ролі маркетингової комунікаційної політики. Ефективна комунікація із цільовим сегментом $\epsilon$ вирішальним фактором ефективної та успішної діяльності підприємства. Маркетологи доводять, що споживач потребує не просто виготовлення продукту, який відповідає їх потребам, а потребує комунікації зі своїм виробником. Така тенденція спостерігається в усьому світі та впливає на формування культури споживання [2].

Політика комунікацій, це один із можливих способів спілкування поміж суб'єктами, містить задум налагодження каналів комунікації із цільовою аудиторією. Сформований комунікаційний канал між виробником товару i покупцями сприяє задоволенню їх взаємних бажань внаслідок чого підприємства-виробники виконують роль відправника інформаційного повідомлення та отримувача. Їхня мета проінформувати/нагадати споживача про товар, стимулювати до здійснення покупок, які відповідають їхнім інтересам. Водночас, підприємства націлюються на обраний ринок задля того, аби опрацьовувати ризиковані повідомлення, пристосовуватись до нестабільного ринкового становища, швидко реагувати до можливого комунікаційного простору, який виник завдяки тій чи іншій ситуації. Тому такий обмін можна назвати як «курс 3 двобічним рухом». 3 одного боку, виробники, які хочуть отримати якнайбільше даних 3 зовнішніх ринків, а 3 іншого боку ефективно анонсувати особисту інформацію до цільової аудиторії.

Формування маркетингової комунікаційної політики вкрай необхідне для того, аби суспільство отримувало більше інформації про принципи діяльності підприємства, його мету та місію, аби детально ознайомити 3 торговою маркою, історією підприємства, процесом виробництва та встановлення цін на продукцію. У конкурентному становищі до одних із головних цілей комунікацій додається ще те, що завдяки їм можна збільшити ринкову частку підприємства, збільшити цільовий сегмент, утримувати позитивний імідж та високу ринкову позицію організації [3].

Аналіз останніх досліджень і публікацій. Проблемам формування та впровадження ефективної комунікаційної політики приділена увага багатьма іноземними та вітчизняними ученими [1-12]. У своїх дослідженнях науковці формують спільне бачення маркетингової комунікаційної політики як інструментів які сприяють досягненню підприємницьких цілей у вибраному сегменті ринку, а також спільними є бачення авторів щодо мети. Попри наявність певного масиву публікацій щодо ефективності маркетингової комунікаційної політики та факторів які на неї впливають дане питання вимагає подальшого перегляду як в теоретичній, так і практичній площині

Мета статті полягає у виявленні сутності маркетингової комунікаційної політики, виділення дієвих маркетингових інструментів та дослідження ключових аспектів інтегрованих маркетингових систем. 
Виклад основного матеріалу. В сучасних умовах ринкової діяльності застосування тільки узагальнених та стандартних способів виведення продукту на ринок (продаж якісної продукції, формування конкурентної ціни, зниження собівартості, стандартизації процесів виробництва, мінімізації маркетингових витрат тощо) є непридатним для довготривалого існування на ринку. Через наявність товарів-аналогів власний продукт може бути незамічений цільовою аудиторією. Тож успішне просування товару на ринку неможливе без продуманого процесу маркетингової комунікаційної політики, яка формується на основі факторів інформування, посилення довіри до виробника, нагадування покупцю про наявність та функціонал товару, покращення збуту, напрацювання лояльного ставлення збоку споживача та покращення сприятливого й пізнаваного іміджу підприємства.

Система маркетингових комунікацій удосконалюється одночасно із економічною та політичною структурою. Проте має місце на існування прямий зв'язок поміж ступенем економічного прогресу суспільства та ступенем посилення функціонування маркетингової комунікації. Можна стверджувати, що маркетингова комунікаційна політика - це комплексне управління процесом просування товару на усіх фазах його існування - від моменту задуму та виготовлення товару, перепродажної підготовки та виходу на ринок, під час продажу, на етапі його використання споживачем та після успішного використання. Для максимальної успішності у створенні комунікаційного плану, потрібно врахувати те що комунікаційна політика буде по-різному сприйматися ринковими суб'єктами. Тому під час налагодження комунікації вчасно реагувати на комунікаційні повідомлення [2].

Сучасний покупець дуже сумнівно відноситься до більшості маркетингових програм,. Тож увагу споживача складно втримати навіть світовим гігантам, які займають лідерські позиції на ринку. Для того щоб запустити результативний продаж обраного товару, необхідно робити набагато більше, аніж обіцяти хороший товар за доступною ціною. Підприємство зобов'язане, пропонуючи свій товар, супроводжувати його цікавими, нестандартними та інформаційними зверненнями, які б спонукали споживачів до повторної купівлі та розповсюдженню позитивної інформації про неї.

Аби отримати швидку реакцію на відправлене повідомлення, маркетологам необхідно здійснити маркетингові дослідження та обрати цільову аудиторію. У маркетингових комунікаціях цільова аудиторія є доволі нестандартним баченням так як не включає в себе суто споживача чи потенційного покупця, а передбачає формування комунікаційних каналів між усіма зацікавленими сторонами які мають вплив на функціонування підприємства. До прикладу, до зовнішньої цільової аудиторії належать клієнти (минулі, теперішні, майбутні), продавці (посередники, оптові та роздрібні торгівці), конкуренти, постачальники та інші (державні установи та громадські організації), а до внутрішньої цільової аудиторії належать працівники 
компанії, акціонери [2]. Тому процес маркетингової комунікації являється основним змістовим аспектом суспільного взаєморозуміння, однією із найвагоміших узагальнюючих характеристик кожної сфери діяльності, в тому числі і управлінської. Вона є сучасною формою політичних, організаційних, наукових i технічних сил, завдяки яким організація має можливість взаємодіяти із зовнішнім оточенням і проводити обмін ідеями та намірами, задля подальшого взаємо порозуміння.

Немаловажним $є$ питання підвищення ефективності комунікаційної політики, яка за своїм характером має ціннісний i семантичний аспекти, психологічно-соціальний, логічно-текстовий, технічний та організаційний. У випадку неефективної комунікації їі цінність знижується. Це, як правило, відбувається під час формування i передачі повідомлення, коли зроблено недостовірне опрацювання інформації, втрата змісту через низьку кваліфікованість персоналу, недотримання часових параметрів або ж занадто швидку подачу інформації без перевірки й уточнення внаслідок чого час адаптації споживача до інформації зменшується, а також втрачається суть запланованої комунікаційної програми [4].

Щодо суб’єктів комунікаційної політики, то серед основних можна виділити: постійних партнерів по бізнесу, підприємства які займаються організацією масових рекламних заходів, дистрибуцію або дилерів, участь у виставках чи ярмарках, зв’язки 3 громадськістю i персональні продажі. Ефективна комунікація з ними можлива за умови [4]:

- застосування інструментів комунікації у комплексі із формуванням інтегрованої маркетингової програми як виду комунікаційної діяльності, яка характеризується специфічними синергетичними ефектами, що виникають в результаті суміщення директ-маркетингу, реклами, зв'язку з громадськістю, комунікаційних інструментів і наборів запланованих повідомлень;

- деталізованої обробки будь-якого інструменту, яка формує комунікаційні канали, які характеризуються самодостатністю, зобов'язані зацікавити споживача, виокремити маркетингову компанію поміж конкурентів, подавати необхідну інформацію якнайшвидше, пришвидшити процес формування довготермінових відносин із клієнтами;

- використання і дотримування стратегії єдності комунікацій. Цей принцип дає змогу покращити ефективність маркетингових каналів та зменшити відсоток негативних повідомлень. Організація єдності комунікації вимагає узгодження інформаційних потоків між собою, що стосується розповсюдження інформаційних блоків щодо рівня розвитку компанії, технологій виробництва, які використовує підприємство, властивостей товару який пропонується тощо. Тобто даний процес фіксує індивідуальний та ексклюзивний ідентифікатор підприємства. Відповідно носії цієї інформації, споживачі, мають на меті ідентифікувати підприємство серед конкурентів. 
Застосування єдиного інформаційного каналу не дає змоги утворити достатній інформаційний простір через що у можливих споживачів i потенційних бізнес-партнерів виникає недостатнє інформування про переваги співпраці із підприємством, внаслідок чого зменшується кількість підписаних контрактів та втрата частки партнерів. Потрібно зауважити, що усі комунікаційні канали мають свої ознаки як у статистиці обхватів, так і у манері донесення меседжу співучасниками комунікаційного руху, який має декілька етапів [3]. Зокрема, відправник (компанія) шифрує зміст посилання у формулу, яка загальноприйнята для рекламних роликів чи інших видів звернення і надсилає це кодування через засоби розповсюдження інформації (радіо, телевізійні програми, інтернет). Отримувач (клієнт) одержує зашифровану інформацію, шляхом перегляду або прослуховування реклами i дешифрує отримане повідомлення, черпаючи від нього потрібну інформацію про продукт чи послугу. Слід врахувати те що, на кожному етапі є перешкоди, які можуть недостовірно передати зміст інформації. Усі етапи комунікаційного процесу формуються задля того аби досягти бажаної мети. Звідси слідує, що метою комунікаційної політики можна назвати результативну взаємодію об'єктів комунікації із суб'єктом комунікаційного простору. Головним завданням цієї політики $\epsilon$ детальна характеристика способів, норм та законів комунікацій, формування заборони на використання неправдивих, нечітких, недостовірних посилань, котрі не виправдовують і не виконують усі поставлені цілі та завдання комунікаційних каналів.

Більшість маркетингових комунікацій зосереджені на вирішенні наявних проблем та завдань на основі яких і формуються цілі плану комунікаційного процесу. Як правило, до основних цілей відносяться [3]: формування у споживача позитивного враження про торгову марку; розповсюдження інформації про існування бренду; спонукання споживача до покупки товару; створення прихильності клієнта до діяльності компанії; формування звички у потенційного покупця; збільшення аудиторії шляхом масового стимулювання збуту; пошук нових клієнтів та бізнес партнерів; завоювання більшої частки ринку; витіснення конкурентів із можливого цільового ринку.

Узагальнивши основні оперативні цілі комунікаційної політики, можна сформувати стратегічні цілі до яких належать: формування попиту у споживача, стимулювання збуту продукції, розроблення пропозицій партнерства в бізнесі (B2B) [6].

Щодня специфіка діяльності та функціонування ринку змінюється і все більше компаній віддають перевагу інтегрованим системам комунікацій. Це вимагає аналізу продуктивності всіх каналів комунікації та формує у споживача чітке, послідовне та аргументоване бачення про компанію та товар, який він обирає. Першочергове місце в аналіз займає детальне планування 
етапів щодо просування товарів на ринок, залучення інвестицій у його розвиток на усіх етапах життьового циклу. Водночас для результативного запровадження у діяльність зовнішніх маркетингових інструментів необхідно налаштувати внутрішню політику комунікацій. Тому інтегрованими маркетинговими комунікаціями називають двосторонній процес, який з однієї сторони прогнозує вплив на обрану аудиторію, а 3 іншої пришвидшує отримання інформації про відгуки цієї аудиторії на запрограмований компанією вплив. Ці два процеси $є$ важливими i на підставі їхньої взаємозалежності можна стверджувати про інтегровану комунікацію як про специфічну систему. Тож нами було виокремлено три основні аспекти на яких базується інтеграційна маркетингова система (рис. 1) [5].

Підсилення одного маркетингового інструменту іншим можливе лише тоді, коли зберігається єдиний механізм в межах будь-яких цільових сегментів. Основним і важливим принципом впровадження інтегрованих маркетингових систем є взаємопідтримка усіх інструментів. Якщо суб'єкти комунікаційного каналу не будуть дотримуватися принципу єдності виникнуть ряд проблем які знизять рівень ефективності каналу, зокрема [7]:

1. Сучасний покупець здійснюючи замовлення чи покупку товару, часто керується не раціональним та не економічним підгрунтям про товар, а тим що видається йому більш привабливим або красивішим. Багаторічні дослідження показують, що зберігається тенденція збільшення неграмотності покупця, адже все менше і менше часу виділяється на покупку товару, в результаті чого споживач може навіть не прочитати склад чи інструкцію до використання цього товару. Тож виникає потреба підлаштовувати комунікаційні інструменти переходячи від усних до візуальних блоків інформацій для кращого сприйняття товару споживачем та формування у нього споживацької грамотності.

\begin{tabular}{|c|c|c|}
\hline Інтеграція вибору & Інтеграція позиціонування & Інтеграція план-графіку \\
\hline $\begin{array}{c}\text { Як найефективніше } \\
\text { сполучити різні засоби } \\
\text { комунікацій (рекламу, } \\
\text { стимулювання збуту, } \\
\text { персональний продаж) для } \\
\text { досягнення цілей } \\
\text { комунікацій }\end{array}$ & $\begin{array}{c}\text { Яким чином кожен з видів } \\
\text { маркетингових комунікацій та } \\
\text { пов’язане } 3 \text { просуванням } \\
\text { рекламне звернення, має бути } \\
\text { погоджено з позиціонуванням } \\
\text { торгової марки з погляду їх } \\
\text { синергічної взаємодії }\end{array}$ & $\begin{array}{c}\text { В яких точках } \\
\text { маркетингових каналів } \\
\text { засоби стимулювання } \\
\text { досягають до споживачів і } \\
\text { прискорюють їхні рішення } \\
\text { на користь даної торгової } \\
\text { марки }\end{array}$ \\
\hline
\end{tabular}

Pис. 1. Ключові аспекти інтегрованих маркетингових систем

2. На ринку засобів масової інформації $\epsilon$ дуже велика кількість можливих варіантів продажу рекламних послуг, що суттєво знизило піi результативність через відсутність, в т.ч. цензури. Всім відомо що рекламний бізнес приносить великі прибутки їх власникам часто порушуючи встановлені 
законодавчі обмеження. Водночас, через стихійність таких послуг реклама втратила свою ефективність, адже при наявності великої кількості телевізійних каналів, радіостанцій та інших засобів масової інформації, посилання які формує компанія для своїх споживачів, губляться та не залишаються у пам'яті внаслідок чого компанії несуть збитки від використання реклами.

3. Часто підприємці нехтують інноваційними каналами комунікацій, які з'являються через що знижується ефективність застосування стандартних комунікаційних каналів. Переключитись від стандартних каналів до інноваційних насправді не важко, проте більшість підприємницьких структур не можуть цього зробити, адже для цього потрібно витратити час та ресурси. Прикладом сучасних каналів комунікації можуть бути оптимізація власних соціальних мереж, розробка SMM програм та створення таргетованої реклами.

Висновки. Отже, досліджуючи маркетингові комунікації встановлено, що вони формують інформаційну взаємодію між виробниками товару та їх споживачами задля покращення іміджу та пізнаваності компанії, шляхом застосування комунікаційних складових маркетингової комунікаційної політики.

Головним завданням маркетингової комунікаційної політики є детальна характеристика способів, норм та законів комунікацій, формування заборони на використання неправдивих, нечітких, недостовірних посилань, котрі не виправдовують і не виконують усі поставлені цілі та завдання комунікаційних каналів.

\section{Лimepamypa:}

1. Хмаррська I.A. Сутність та значення комплексу маркетингових комунікацій підприємств / I.А. Хмаровська // Вісник Хмельницького національного університету. - 2011. № 6, T. 2. - C.114-118.

2. Балабанова Л.В. Маркетинг : підручник / Л.В. Балабанова. 2-е вид., перероб. і дооп. К. : Знання-Прес, 2004. - 645 с.

3. Карпенко Н.В. Комплекс маркетингових комунікацій у стратегічному управлінні маркетинговою діяльністю підприємства : монографія / Н. В. Карпенко, Н. І. Яловега. - Полтава : ПУЕТ, 2012. - $278 \mathrm{c.}$

4. Братко О.С. Маркетингова політика комунікацій: навчальний посібник / О.С. Братко. Тернопіль : Карт-бланш, 2006. - 275 с.

5. Богун Л.Ю. Класифікація інтегрованих маркетингових комунікацій у місцях продажу / Л.Ю. Богун, С.Б. Розумей // Науковий вісник Міжнародного гуманітарного університету. Серія : Економіка і менеджмент. - 2017. - Вип. 24(1). -С. 79-82.

6. Ковінько О.М. Проблеми формування ефективної комунікаційної політики на прикладі комунального підприємства / О.М. Ковінько, С.М. Дєдов // Молодий вчений. - 2016. - № 12 (39). - С. 756-759.

7. Войнаренко С.М. Ключові фактори успіху в комунікаційній політиці підприємств / С.М. Войнаренко // Вісник Хмельницького національного університету. Економічні науки. Хмельницький. - 2007. - № 6, Т. 1. - С. 231-233.

8. Скупейко В.В., Лихолат С.М., Вознюк О., Грицайко А. Вплив життєвого циклу підприємства на вибір маркетингової стратегії / В.В. Скупейко, С.М. Лихолат, О. Вознюк, А. Грицайко // Наукові записки Львівського університету бізнесу та права. - 2019. - № 23. - с. 85-89 (232 с.). 
9. Говард Д., Шет Д. Теория поведения покупателя. Классика маркетинга. Сборник работ, оказавших наибольшее влияние на маркетинг / Д. Говард., Д. Шет // пер. с англ. СПб. : Питер. 2001. - С. 175-198.

10.Войнаренко С.М. Комунікативна політика підприємств в сучасних умовах / С.М. Войнаренко // Вісник Хмельницького національного університету. - 2011. - № 6. Т. 2. - С. 51-54.

11. Лихолат С.М., Крикавський Є.В., Скупейко В.В., Шинкаренко Н.В., Петецький I. Вплив маркетингової комунікаційної політики на транспарентність банків / С.М. Лихолат, Є.В.Крикавський, В.В. Скупейко, I. Петецький // Ефективна економіка. - 2021. № 7. http://www.economy.nayka.com.ua/pdf/7_2021/72.pdf

12. Ярошевська О. В. Комплекс маркетингових комунікацій та його роль у системі маркетингу / О.В. Ярошевська // Вісник Запорізького національного університету. Економічні науки. - 2011. - № 3 (11). - С. 146-154.

\section{References:}

1. Khmarrska, I. A. (2011). Sutnist ta znachennia kompleksu marketynhovykh komunikatsii pidpryiemstv [The essence and significance of the complex of marketing communications of enterprises]. Visnyk Khmelnytskoho natsionalnoho universytetu, 6, 114-118 [in Ukrainian].

2. Balabanova, L. V. (2004). Marketynh [Marketing]. Kyiv: Znannia-Pres [in Ukrainian].

3. Karpenko, N. V., \& Yaloveha N. I. (2012). Kompleks marketynhovykh komunikatsii u stratehichnomu upravlinni marketynhovoiu diialnistiu pidpryiemstva [Complex of marketing communications in strategic management of marketing activity of the enterprise] [in Ukrainian].

4. Bratko, O. S. (2006). Marketynhova polityka komunikatsii [Marketing communications policy]. Ternopil : Kart-blansh [in Ukrainian].

5. Bohun, L. Yu., \& Rozumei, S. B. (2017). Klasyfikatsiia intehrovanykh marketynhovykh komunikatsii u mistsiakh prodazhu [Classification of integrated marketing communications at points of sale]. Naukovyi visnyk Mizhnarodnoho humanitarnoho universytetu. Seriia : Ekonomika $i$ menedzhment, 24(1), 79-82 [in Ukrainian].

6. Kovinko, O. M., \& Diedov, S. M. (2016). Problemy formuvannia efektyvnoi komunikatsiinoi polityky na prykladi komunalnoho pidpryiemstva [Problems of forming an effective communication policy on the example of a utility company]. Molodyi vchenyi, 12 (39), 756-759 [in Ukrainian].

7. Voinarenko, S. M. (2007). Kliuchovi faktory uspikhu v komunikatsiinii politytsi pidpryiemstv [Key success factors in the communication policy of enterprises]. Visnyk Khmelnytskoho natsionalnoho universytetu. Ekonomichni nauky, № 6, T. 1., 231-233 [in Ukrainian].

8. Skupeiko, V. V., Lykholat, S. M., Vozniuk, O., \& Hrytsaiko A. (2019). Vplyv zhyttievoho tsyklu pidpryiemstva na vybir marketynhovoi stratehii [The influence of the life cycle of the enterprise on the choice of marketing strategy]. Naukovi zapysky Lvivskoho universytetu biznesu ta prava 23, 8589 (232 s.) [in Ukrainian].

9. Hovard, D., \& Shet D. (2001). Teoryia povedenyia pokupatelia. Klassyka marketynha. Sbornyk rabot, okazavshykh naybolshee vlyianye na marketynh [Theory of buyer behavior. Classics of marketing. A collection of works that have had the greatest impact on marketing], SPb. : Pyter. [in Rusian].

10. Voinarenko, S. M. (2011). Komunikatyvna polityka pidpryiemstv v suchasnykh umovakh [Communicative policy of enterprises in modern conditions], 6. T. 2, 51-54 [in Ukrainian].

11. Lykholat, S. M., Krykavskyi, Ye. V., Skupeiko, V. V., Shynkarenko, N. V., \& Petetskyi I. (2021). Vplyv marketynhovoi komunikatsiinoi polityky na transparentnist bankiv [The impact of marketing communication policy on bank transparency]. Efektyvna ekonomika, 7. Retrieved from http://www.economy.nayka.com.ua/pdf/7_2021/72.pdf [in Ukrainian].

12. Yaroshevska, O. V. (2011). Kompleks marketynhovykh komunikatsii ta yoho rol u systemi marketynhu [Complex of marketing communications and its role in the marketing system]. Visnyk Zaporizkoho natsionalnoho universytetu. Ekonomichni nauky, 3 (11), 146-154 [in Ukrainian]. 